\title{
PENGEMBANGAN MODEL SIMULASI SISTEM DINAMIK UNTUK MENINGKATKAN EFISIENSI SISTEM OPERASIONAL TRANSPORTASI
}

\author{
Amaliah Faradibah ${ }^{1}$, Erma Suryani ${ }^{2}$ \\ 1amaliah.af@gmail.com, ${ }^{2}$ erma.suryani@gmail.com² \\ 1,2Institut Teknologi Sepuluh Nopember
}

\begin{abstract}
Abstrak
Jika transportasi terus meningkat, dan persaingan produsen transportasi terus meningkat maka peningkatan pengguna transportasi akan terus meningkat dan akan menyebabkan kemacetan. Kemacetan adalah faktor yang sangat mempengaruhi efisiensi sistem transportasi, dimana sistem transportasi adalah bentuk lampiran dan saling berhubungan antara penumpang, angkutan dan infrastruktur yang berinteraksi untuk mentransfer orang atau barang, yang tercakup dalam suatu pesanan, baik secara alami atau buatan atau direkayasa. Ini membutuhkan strategi perencanaan yang tepat dalam mengatasi kondisi kemacetan seperti penerapan konfigurasi ulang jaringan rute, program yang menggunakan sistem dinamis dalam desain dan perencanaan yang tepat, dan penentuan skenario yang paling tepat dapat meningkatkan efisiensi sistem transportasi. Penelitian ini menggunakan skenario melalui rekonfigurasi rute jaringan untuk meningkatkan efisiensi sistem transportasi. Dalam penelitian ini, skenario ini dianggap sebagai yang paling tepat untuk meningkatkan efisiensi waktu perjalanan kendaraan dengan cara transfer rute kendaraan ringan yang akan menuju jalan Urip Sumoharjo karena menghasilkan pengurangan waktu tempuh sebesar $1.2 \%$ waktu perjalanan sebelum skenario.
\end{abstract}

Kata kunci: Sistem Transportasi, Efisiensi, Kemacetan Lalu Lintas, Sistem Dinamik

\begin{abstract}
If transport continues to increase, plus manufacturers competing to produce interesting transportation on the market, thus allowing the improvement of the transport users. If the increase occurs, it will cause congestion. Congestion was a factor that greatly affect the efficiency of the transport system, where the transportation system is a form of attachment and the interconnected between the passenger, shuttles and infrastructure that interact in order to transfer people or goods, which is covered in an order, either by natural or artificial or engineered. It takes the right planning strategies in addressing conditions congestion such as implementation of reconfiguration of the route network, a program that using dynamical systems in proper design and planning, and the determination of the most appropriate scenario can improve the efficiency of the transportation system. This research uses scenario through reconfiguration of network routes to improve the efficiency of the transportation system. in this study, this scenario is considered to be the most appropriate to increase the efficiency of vehicle travel time by way of the transfer of light vehicle routes that will go towards the Urip Sumoharjo street because it results in a reduction in travel time by $1.2 \%$ of travel time before the scenario.
\end{abstract}

Keywords: Transportation System, Efficiency, Traffic congestion, System Dynamics

\section{Pendahuluan}

Pertumbuhan ekonomi yang sangat tinggi menimbulkan dampak perpindahan penduduk dari pedesaan ke perkotaan. Hal ini mengakibatkan pertumbuhan penduduk diperkotaan dalam 20 tahun terakhir rata-rata mencapai kisaran 3-5\%. Berdampak lebih tinggi dari pertumbuhan penduduk nasional yang rata-rata sebesar $2 \%$ [1] . Sejumlah aktifitas yang sering dilakukan oleh manusia paling banyak menggunakan transportasi darat dibandingkan transportasi laut dan udara. Kebutuhan transportasi yang terus meningkat, menyebabkan persaingan produsen meningkat, dalam memproduksi moda transportasi. Sistem transportasi merupakan suatu kesatuan dari fasilitas fisik (tetap), arus dan sistem kontrol yang memungkinkan manusia dan barang untuk berpindah dari satu tempat ke tempat yang lain secara efisien dalam rangka memenuhi kebutuhan. Sistem transportasi berfungsi untuk mengatur transportasi yang ada, seperti aturan-aturan dan penyediaan fasilitas dalam menggunakan alat transportasi. Tujuan dari sistem transportasi adalah untuk mencapai proses transportasi penumpang dan barang secara optimum dalam ruang dan waktu tertentu, dengan mempertimbangkan faktor keamanan, kelancaran dan kenyamanan, serta waktu dan biaya. 
ILKOM Jurnal Ilmiah Volume 11 Nomor 1 April 2019 Terakreditasi peringkat 3 SK. No. 28/E/KPT/2019

Menurut Jeihani et,al., dan Bifulco et al, Beberapa faktor/variabel terbesar yang mempengaruhi arus lalu lintas dalam sistem transportasi yaitu kemacetan, kemacetan dapat disebabkan oleh adanya gangguan yang tidak terduga seperti kecelakaan, pengerjaan jalan dan kerusakan jalan serta kondisi cuaca yang buruk [2], dapat juga disebabkan adanya hambatan lalu lintas, biasanya terkait dengan adanya bus, truk atau kendaraan lambat lainnya yang berada di jalur lalu lintas perkotaan [3].

Seperti yang telah dijelaskan sebelumnya bahwa yang menjadi pokok permasalahan dari faktor keamanan, kelancaran dan kenyamanan, serta waktu dan biaya adalah kemacetan. Kemacetan lalu lintas sering kali terjadi adalah saat volume kendaraan lebih besar dari kapasitas ruas jalan, Kemacetan atau keadaan dimana kecepatan kendaraan sangan minim akan mempengaruhi waktu tempuh atau perjalanan yang dirasakan pengemudi menjadi lebih lama, dan polusi udara yang dapat mempengaruhi lingkungan sekitar yang akan menimbulkan pemanasan global, serta dapat menyebabkan tingginya asupan bahan bakar. Sistem transportasi memfokuskan beberapa titik yang perlu dilakukan efisiensi sebelum sampai kepada keseluruhan dari efisiensi sistem transportasi khususnya efisiensi terhadap waktu tempuh kendaraan. Tindakan yang dapat dilakukan dalam meningkatkan efisiensi waktu tempuh sistem operasional transportasi yaitu Pemberian informasi panduan kepada pengemudi untuk melakukan perutean ulang dengan tujuan dapat mengurangi waktu tempuh kendaraan.

\section{Metode}

\subsection{Sistem Transportasi}

Morlok., 1978, Transportasi adalah suatu tindakan, proses, atau hal memindahkan atau sedang dipindahkan dari suatu tempat ke tempat yang lain. Manurut Fidel Miro, 2002, Transportasi adalah usaha memindahkan, menggerakkan, mengangkut dan mengalihkan suatu objek dari suatu tempat ke tempat lain, di mana di tempat lain objek tersebut lebih bermanfaat atau dapat berguna untuk tujuantujuan tertentu [4].

Fasilitas dan peralatan pendukung utama dari semua mode ini dan sistemnya adalah pensinyalan lalu lintas, kontrol, sistem manajemen, sistem pasokan daya, dan fasilitas / peralatan untuk memfasilitasi dengan pelanggan termasuk administrasi. Infrastruktur, kendaraan, dan fasilitas dan peralatan moda transportasi dan sistem mereka dioperasikan dan dipelihara oleh pekerja yang berkualitas dan berdedikasi [4].

\subsection{Lalu lintas dan angkutan jalan}

Lalu lintas (traffic) adalah kegiatan lalu-lalang atau gerak kendaraan, orang atau hewan di jalanan. Masalah yang dihadapi dalam perlalulintasan adalah keseimbangan antara kapasitas jaringan jalan dengan banyaknya kendaraan dan orang-orang yang berlalu lalang menggunakan jalan tersebut. Jika kapasitas jaringan jalan sudah hampir jenuh, apalagi terlampaui maka yang terjadi adalah kemacetan lalu lintas. Persoalan ini sering dirancukan sebagai persoalan angkutan.

Angkutan (transport) adalah kegiatan perpindahan orang atau barang dari satu tempat (asal) ke tempat lain (tujuan) dengan menggunakan sarana (kendaraan). Bila kapasitas armada lebih rendah dari yang dibutuhkan, akan banyak barang maupun orang yang tidak terangkut, atau keduanya dijejalkan pada kendaraan yang ada [5].

Unsur dasar lalu lintas dan angkutan jalan adalah sama, yakni :

1) Ruang kegiatan berupa lahan yang ditata kegunaannya

2) Ruang lalu lintas berupa jalan, jembatan dan penyeberangan.

3) Simpul berupa terminal (terminal bus, stasiun kereta api, pelabuhan, Bandar udara).

Jaringan prasarana lalu lintas dan angkutan jalan terdiri atas ruang lalu lintas berupa jalan (termasuk jembatan), dan simpul lalu lintas yang berujud terminal. Jalan adalah ruang lalu lintas tempat kendaraan dan ruang bergerak untuk berpindah tempat. Jalan, sebagaimana didefinisikan, diperuntukkan bagi lalu lintas umum [UU-RI No.14 Th 1992]. Berdasarkan fungsikan jalan dipilah-pilah sebagai berikut[5]:

1. Jalan : Dalam penataan jaringan jalan agar tersusun sistem jaringan yang baik, harus diperhatikan tata jenjang (hierarki) jaringan. Tata jenjang jaringan jalan akan mengarah pada susunan sistem pelayanan jasa angkutan jalan yang kemudian menjadi sistem sirkulasi lalu lintas di jalan.

2. Pengelolahan lalu lintas : Sebagaimana telah diutarakan, komponen lalu lintas terdiri atas manusia (pengguna jalan), kendaraan, dan jalan yang saling berkaitan dan satu sama lain saling mempengaruhi. Oleh karena itu, 'sasaran' pengelolaan lalu lintas adalah pada ketiga komponen tersebut diatas. Opaya mengelola lalu lintas pada dasarnya adalah upaya mengoptimalkan 
kapasitas jaringan jalan untuk menampung volume lalu lintas yang ada dan atau diperkirakan akan terjadi.

3. Rekayasa lalu lintas : Dalam rangka pelaksanaan pengelolaan lalu lintas di jalan dilakukan rekayasa lalu lintas [PP No.43 Th. 1993] yang meliputi:

- Perencanaan, pembangunan dan pemeliharaan jalan.

- Perencanaan, pengadaan, pemasangan, dan pemeliharaan rambu-rambu, marka jalan, alat pemberi isyarat lalu lintas serta alat pengendali dan pengeman pemakai jalan.

\subsection{Efisiensi}

Efisiensi adalah suatu cara dengan bentuk usaha yang dilakukan dalam menjalankan sesuatu dengan baik dan tepat serta meminimalisir pemborosan dalam segi waktu, tenaga dan biaya [6]. Adapun untuk mencari tingkat efisiensi dapat digunakan rumus (1) sebagai berikut :

$$
\text { Efisiensi }=\text { Outputt/Input }>=1
$$

1. Jika output berbanding input lebih besar atau sama dengan 1 (satu), maka akan terjadi efisiensi.

2. Jika output berbanding input kurang daripada 1 (satu), maka efisiensi tidak tercapai.

Menurut Muchdoro (1997:180) "Efisiensi adalah tingkat kehematan dalam menggunakan sumber daya yang ada dalam rangka mencapai tujuan yang diinginkan. Efisiensi terbagi menjadi dua, yaitu efisiensi waktu dan efisiensi biaya. Efisiensi waktu adalah tingkat kehematan dalam hal waktu saat pelaksanaan hingga kapan proyek itu selesai. Sedangkan efisiensi biaya adalah tingkat kehematan dan pengorbanan ekonomi yang dilakukan untuk mencapai tujuan yang telah ditetapkan".

\subsection{Sistem Dinamik dan Simulasi}

Menurut Forrester, 1994, Sistem dinamik merupakan kerangka yang memfokuskan pada sistem berpikir dengan cara feedback loop dan mengambil beberapa langkah tambahan struktur serta mengujinya melalui model simulasi komputer [7].

Pengertian simulasi menurut Khoshnevis 1994 yang dituliskan dalam penelitian sebelumnya menyatakan bahwa Simulasi merupakan proses aplikasi membangun model dari sistem nyata atau usulan sistem, melakukan eksperimen dengan model tersebut untuk menjelaskan perilaku sistem, mempelajari kinerja sistem atau untuk membangun sistem baru sesuai dengan kinerja yang diinginkan. Penggunaan simulasi akan memberikan wawasan yang lebih luas pada pihak manajemen dalam menyelesaikan suatu masalah.oleh karena itu manfaat yang didapat dengan menggunakan metode simulasi adalah sebagai tool bagi perancang sistem atau pembuat keputusan, dalam hal ini manajer untuk menciptakan sistem dengan kinerja tertentu baik dalam tahap perancangan sistem (untuk sistem yang masih berupa usulan) maupun tahap operasional (untuk sistem yang berjalan) [6].

\subsection{Kota Makassar}

Kota Makassar mempunyai penduduk total sebanyak 1.408.004 jiwa (Badan Pusat Statistik Kota Makassar, 2013). Jumlah penduduk 392.716 jiwa dengan pertumbuhan rata-rata sebesar $3,17 \%$. Sedangkan wilayah perkembangan kota ke arah selatan (Kecamatan tamalate) mempunyai jumlah penduduk 325.037 jiwa dengan pertumbuhan 2,09 \%. Pertumbuhan penduduk di kedua wilayah suburban tersebut lebih besar daripada pertumbuhan penduduk di Kota Makassar (1,63\%). Kota Makassar memiliki tingkat kepadatan penduduk yang cukup tinggi, sehingga jumlah transportasi yang ada juga sangat banyak. Melihat kondisi lalu lintas saat ini, beberapa jalan di kota Makassar sering mengalami kemacetan. Makassar memiliki jalan yang sangat rentang terhadap kemacetan karena tidak memiliki jalan alternative atau rute lain yang cukup banyak.

\subsection{Tahapan Penelitian}

Tahapan penelitian menguraikan setiap tahapan yang dilakukan dalam penelitian ini, berikut ini adalah langkah-langkah dalam penelitian ini:

\section{a. Identifikasi Masalah}

Identifikasi masalah pada penelitian ini merupakan studi kasus dimana penilitian ini bertujuan untuk menghasilkan sistem transportasi yang efisien. Identifikasi masalah dilakukan untuk menemukan research question yang dikemukakan pada penelitian terdahulu dalam meningkatkan efisiensi sistem transportasi dengan mengurangi kemacetan. 


\section{b. Studi Literatur}

Studi literatur dalam penelitian diambil dari beberapa sumber buku, media, ataupun dari hasil penelitian orang lain. Studi ini membantu dalam merumuskan permasalahan terkait dengan variabel yang dapat mempengaruhi tingkat efisiensi dari sistem transportasi untuk waktu tempuh kendaraan.

\section{c. Identifikasi Variabel}

Pada tahap ini dilakukan identifikasi terhadap variabel berdasarkan pada penelitian terdahulu yang membahas tentang efisiensi sistem transportasi untuk waktu tempuh serta penelitian yang berkenaan dengan sistem transportasi seperti penanganan kemacetan dan implementasi infrastruktur dalam meningkatkan lalu lintas, serta fasilitas terkait sistem transportasi yang mendukung kelancaran lalu lintas.

\section{d. Pengumpulan Data}

Pada tahap ini dilakukan pengumpulan data, data diambil dari Dinas Perhubungan kota Makassar, data yang digunakan pada penelitian ini berupa luas jalan dan wilayah, jumlah dan jenis transportasi umum, data jalan lintas kota, jumlah alat transportasi dijalan setiap harinya, waktu kritis kepadatan jalan, pengaturan waktu sinyal lalu lintas, ruas jalan, perubahan kecepatan kendaraan setiap tahunnya. Data tambahan yang dibutuhkan yaitu data penduduk kota Makassar, curah hujan, jumlah kecelakaan, dan pengerjaan jalan.

\section{e. Pengembangan Model}

Pembuatan model konseptual diawali dengan menggambarkan sistem secara umum menggunakan diagram kausal (causal loop) yang akan disimulasikan dengan metode sistem dinamik melalui komponen-komponen yang disajikan dalam gambar. Diagram kausal yang akan dibuat menggambarkan hubungan sistem transportasi yang efisien terhadap waktu tempuh kendaraan.

\section{f. Formulasi dan Identifikasi hasil simulasi}

Sebelum melangkah pada tahap formulasi dan identifikasi, perlu dilakukan penerjemahan dari diagram kausal atau causal loop diagram kedalam model sistem dinamik. Model sistem dinamik akan digambarkan dalam feedback loop diagram yang terdiri dari dua symbol yaitu stock (Level) dan flow (Rate).

\section{g. Validasi Data}

Pada tahap ini aka dilakukan validasi terhadap model dimana data nyata akan diuji menggunakan 2 (dua) tahap yaitu uji perbandingan rata-rata dan uji perbandingan variasi amplitudo. Berikut ini contoh variabel yang akan diuji validasi.

Pengujian pertama menggunakan rumus (2) dan (3) berikut ini :

$$
E 1=\frac{[\bar{S}-\bar{A}]}{\bar{A}}
$$

Dimana :

$\bar{S}=$ nilai rata-rata hasil simulasi

$\bar{A}=$ nilai rata-rata data

Model dianggap valid jika $E 1 \leq 5 \%$

Pengujian kedua menggunakan rumus berikut ini:

$$
E 2=\left|\frac{S_{s}-s_{a}}{s_{a}}\right|
$$

Dimana :

Model dianggap valid jika $E 2 \leq 30 \%$

$S_{s}=$ Standar Deviasi Model

$S_{a}=$ Standar Deviasi Data

\section{h. Penyusunan Skenario}

Pada tahap ini akan dilakukan pengembangan skenario untuk meningkatkan efisiensi sistem transportasi lalu lintas terhadap model. Beberapa simulasi akan dilakukan berdasarkan beberapa skenario yang memungkinkan untuk memberikan pengaruh.

\section{i. Penarikan Kesimpulan}

Tahapan terakhir dalam penelitian ini yaitu menganalisis dan membahas secara menyeluruh temuan dalam penelitian terkait dengan faktor yang mempengaruhi dalam meningkatkan efisiensi sistem transportasi lalu lintas. 
ILKOM Jurnal Ilmiah Volume 11 Nomor 1 April 2019

Terakreditasi peringkat 3 SK. No. 28/E/KPT/2019

\section{Hasil dan Pembahasan}

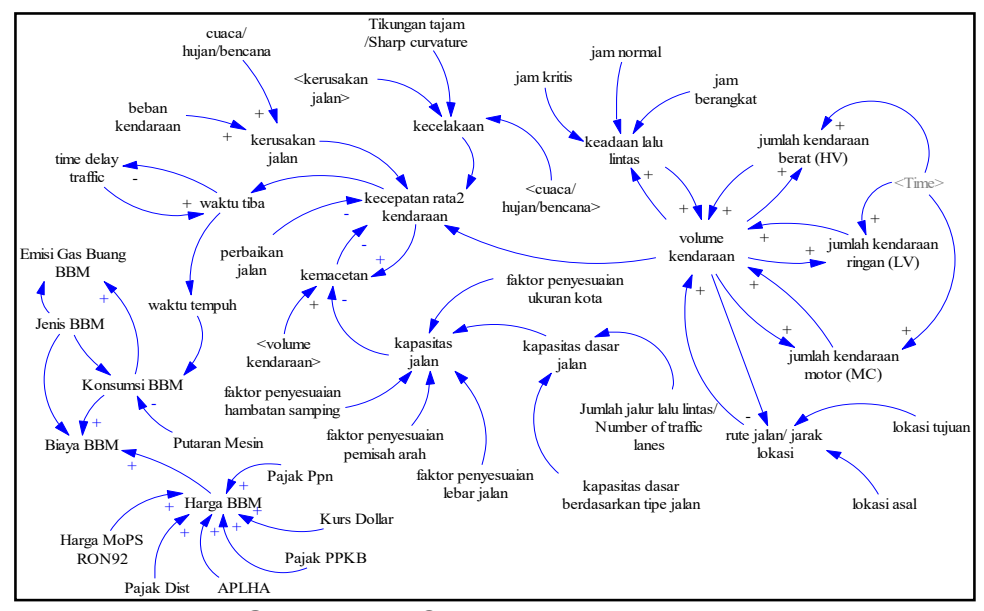

\subsection{Model Development}

Gambar 1. Causal Loop Diagram

Berdasarkan Causal Loop diagram yang telah ditampilkan pada Gambar.1 maka dilakukan analisa untuk setiap hubungan variabelnya, dengan melakukan pemodelan berdasarkan kondisi eksisting dan dikembangkan dengan skenario.

\section{a. Rasio (Volume per Kapasitas Jalan) di Jalan Urip Sumoharjo}

Rasio volume per kapasitas merupakan perbandingan antara volume yang melintas (smp/jam) dengan kapasitas pada suatu ruas jalan tertentu (smp/jam). Besarnya volume lalu-lintas diperoleh berdasarkan analisis data yang dilakukan secara langsung, sedangkan besarnya kapasitas diperoleh dari lingkungan ruas jalan dan menggunakan beberapa paper yang telah melakukan pengukuran survei geometrik sebelumnya.

Adapun persamaan sub model Rasio (volume per kapasitas jalan) di jalan urip sumoharjo berdasarkan Gambar 2 dapat diuraikan berikut ini :

- Aturan besaran HV (smp) $=1.2$

- Jumlah volume HV (smp) di jalan urip sumoharjo = "aturan besaran HV (smp) di jalan Urip Sumohardjo")

- Aturan besaran LV $(\mathrm{smp})=1$.

- jumlah volume LV (smp) di jalan urip sumoharjo = "aturan besaran LV (smp)"*"average jumlah Kendaraan ringan (LV) di jalan Urip Sumohardjo"

- Aturan besaran MC (smp) $=0.25$

- jumlah volume MC (smp) di jalan urip sumoharjo = "aturan besaran HV (smp)"*"jumlah kendaraan berat (HV) di jalan Urip Sumohardjo"

- Total volume kendaraan di jalan urip sumoharjo = jumlah volume HV SMP di jalan urip sumoharjo + jumlah volume MC (smp) di jalan urip sumoharjo

- Rasio (volume per kapasitas jalan) di jalan Urip Sumoharjo = total volume kendaraan di jalan urip sumoharjo / kapasitas lalu lintas di jalan urip sumoharjo

Gambar 3 menunjukan Sub Model Rasio di jalan urip sumoharjo menurun setiap tahunnya, mulai dari tahun $2001 \mathrm{sd}$ 2017. Rasio jalan menurun akibat jalan ini sudah tidak mampu manampung volume kendaraan atau lalu lintas yang meningkat setiap tahunnya. Solusi penurunan rasio juga tidak seimbang karena proses pelebaran jalan hanya dilakukan satu kali dengan menambahkan sebanyak satu jalur untuk masing-masing arah, sehingga rasio menurun pada tahun 2015 yaitu 1.211 sedangkan pada tahun 2016 yaitu 0.971. Namun hasil keputusan akhir pemerintah menyatakan bahwa pelebaran jalan di jalan urip sumoharjo sudah tidak dapat dikerjakan akibat batas area pelebaran atau lingkungan. 
ILKOM Jurnal Ilmiah Volume 11 Nomor 1 April 2019

Terakreditasi peringkat 3 SK. No. 28/E/KPT/2019

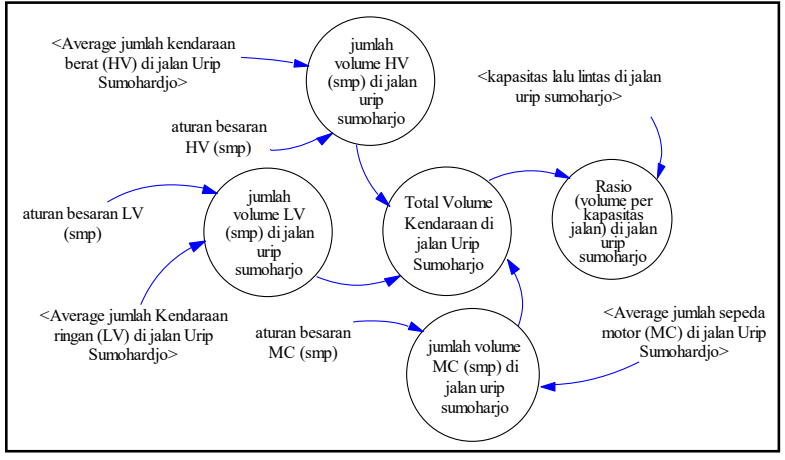

Gambar 2. SFD - Sub Model Rasio (volume per kapasitas jalan) di jalan Urip Sumoharjo

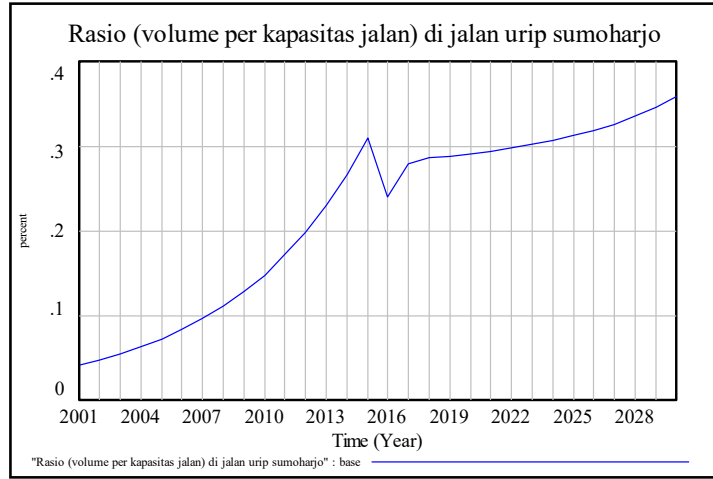

Gambar 3. Grafik SFD - Sub Model Rasio kendaraan dijalan Urip Sumoharjo

\section{b. Rasio (Volume per Kapasitas Jalan) di Jalan Urip Sumoharjo}

Kecepatan rata-rata kendaraan dipengaruhi oleh beberapa faktor yang dapat manurunkan dan meningkatkan kecepatan. Faktor volume lalu lintas dan kapasitas jalan, semakin rendah jumlah volume lalu lintas dari kapasitas jalannya maka semakin tinggi kecepatan lalu lintas tersebut begitupun sebaliknya. Faktor penghambat seperti cuaca, kecelakaan, perbaikan dan gerak u-turn dapat menurunkan angka kecepatan, semakin sedikit hambatan yang dialami pengendara dalam lalu lintas maka semakin tinggi kecepatan lalu lintas.

Adapun persamaan sub model dampak perbaikan jalan terhadap kecepatan lalu lintas berdasarkan Gambar 4 dapat diuraikan berikut ini :

- Kecepatan Rata-rata = IF THEN ELSE(("Kecepatan Rata-rata Kendaraan dalam kota Makassar" (Dampak cuaca terhadap kecepatan kendaraan+Dampak Kecelakaan terhadap Kecepatan + "Dampak Gerak U-turn Terhadap kecepatan" + Dampak Perbaikan jalan terhadap Kecepatan + (Dampak Rasio terhadap kecepatan))) $<=2,0$, ("Kecepatan Rata-rata Kendaraan dalam kota Makassar"-(Dampak cuaca terhadap kecepatan kendaraan + Dampak Kecelakaan terhadap Kecepatan + "Dampak Gerak U-turn Terhadap kecepatan" + Dampak Perbaikan jalan terhadap Kecepatan + Dampak Rasio terhadap kecepatan)))

Gambar 5. menunjukan angka kecepatan rata-rata kendaraan di jalan Urip Sumoharjo, mulai dari tahun 2001 sampai dengan tahun 2017. Kecepatan rata-rata lalu lintas yang terkena hambatan dan tidak memiliki perbedaan angka yang cukup tinggi, data dalam tiga tahun terakhir menunjukan pada tahun 2015 kecepatan rata-rata tanpa hambatan $35.80 \mathrm{~km} / \mathrm{jam}$ dengan hambatan $20.13 \mathrm{~km} / \mathrm{jam}$, pada tahun 2016 kecepatan rata-rata tanpa hambatan $27.90 \mathrm{~km} / \mathrm{jam}$ dengan hambatan $23.79 \mathrm{~km} / \mathrm{jam}$, dan pada tahun 2017 kecepatan rata-rata tanpa hambatan 34.42 km/jam dengan hambatan 20.55 km/jam.

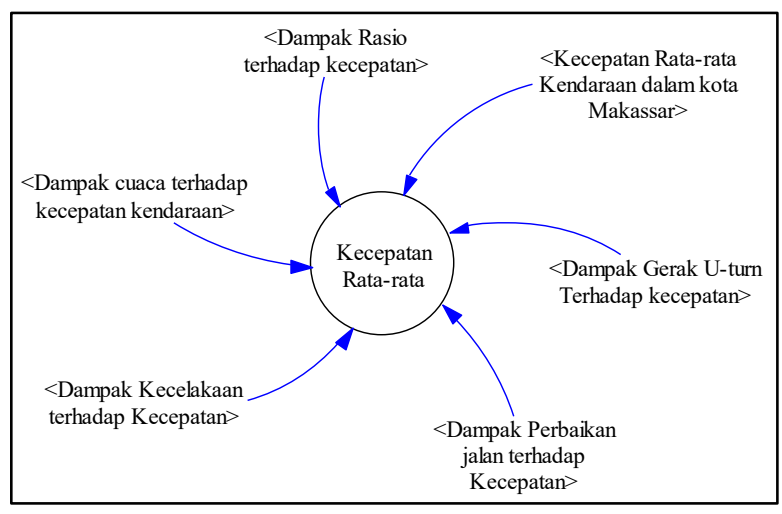

Gambar 4. SFD - Sub Model Kecepatan RataRata Kendaraan

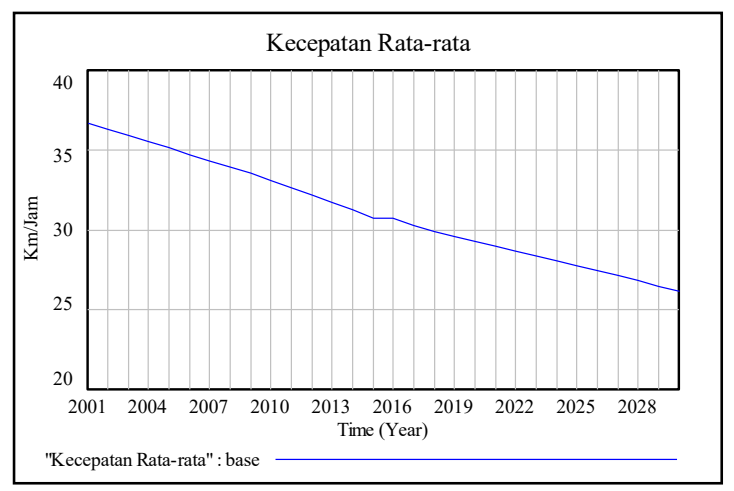

Gambar 5. Grafik Sub Model Kecepatan RataRata Kendaraan

\section{c. Sub Model Waktu Tempuh Kendaraan di Jalan Urip Sumoharjo}

Waktu tempuh kendaraan dipengaruhi oleh beberapa faktor, yaitu kecepatan laju kendaraan dan waktu tunda traffic light. Semakin lambat laju kendaraan maka semakin lama waktu tempuh 
ILKOM Jurnal Ilmiah Volume 11 Nomor 1 April 2019

Terakreditasi peringkat 3 SK. No. 28/E/KPT/2019

kendaraan. Begitupun dengan traffic light, semakin lama waktu tunda traffic light yang di lalui maka semakin lama waktu untuk menempuh jalur atau jalan tersebut.

Adapun persamaan sub model waktu tempuh kendaraan di jalan urip sumoharjo berdasarkan gambar 6 dapat diuraikan berikut ini :

- Waktu Tempuh jalan Urip Sumoharjo = IF THEN ELSE("Kecepatan Rata-rata"=0, 0 , ((Panjang jalan urip sumoharjo/"Kecepatan Rata-rata") + waktu tunda traffic light) )

Adapun nilai parameter sub model waktu tempuh kendaraan di jalan urip sumoharjo yang didapatkan dari hasil dari jarak dibagi dengan kecepatan, berikut ini daftar nilai parameter dan penentuan nilai parameternya yang akan disajikan dalam bentuk tabel.3.

Adapun persamaan sub model efisiensi waktu tempuh kendaraan dapat diuraikan berikut ini :

- Standard Travel Time = Panjang jalan urip sumoharjo/"Kecepatan Rata-rata Kendaraan dalam kota Makassar"

- Trivel Time = Panjang jalan urip sumoharjo/"Kecepatan Rata-rata"

- Travel Time Efficiency = Trivel Time/Standard Travel Time

Gambar 7 menunjukan hasil efisiensi waktu tempuh kendaraan yang melewati jalan urip sumoharjo, mulai dari tahun 2001 sampai dengan tahun 2017. Hasil dalam tiga tahun terakhir menunjukan nilai efisiensi 1.77 pada tahun 2015, 1.17 pada tahun 2016, dan 1.67 pada tahun 2017.

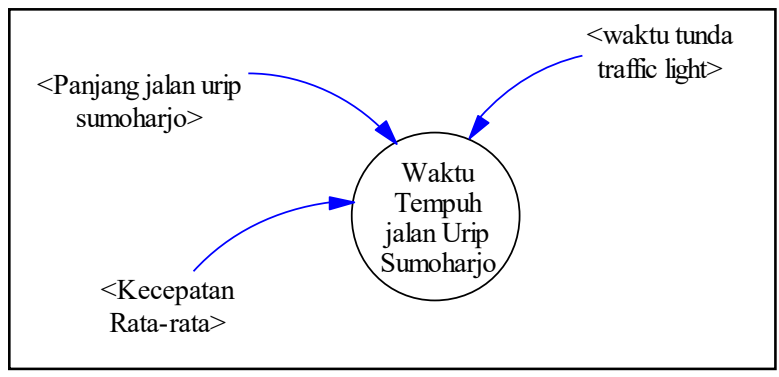

Gambar 6. SFD - Sub Model Waktu Tempuh

Kendaraan di Jalan Urip Sumoharjo

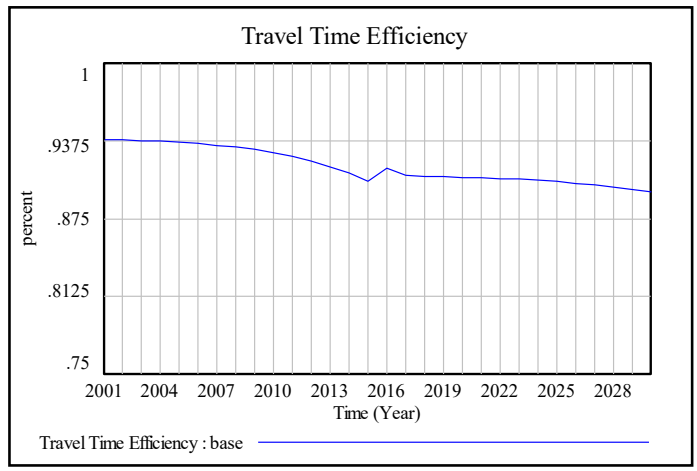

Gambar 7. Grafik Sub Model Efisiensi Waktu Tempuh

\subsection{Model Validation}

Validasi terhadap model dimana data nyata akan diuji menggunakan 2 (dua) tahap yaitu uji perbandingan rata-rata dan uji perbandingan variasi amplitudo.

\section{a. Validasi Sub Model Volume Sepeda Motor (MC) di Makassar}

Validasi sub model volume kendaraan jenis sepeda motor (MC) di Makassar, akan disajikan dalam Tabel 1. Berdasarkan Tabel tersebut menunjukkan hasil validasi dengan nilai uji perbandingan rata-rata $1.34 \%$ dan uji perbandingan variasi amplitude $1.90 \%$. Sesuai dengan standar nilai maksimum validasi data dimana $\mathrm{E} 1 \leq 5 \%$ dan $\mathrm{E} 2 \leq 30 \%$, maka hasil uji dapat dinyatakan bahwa data volume kendaraan jenis sepeda motor valid. Hasil pengujian volume kendaraan jenis sepeda motor (MC) di makassar disajikan dalam bentuk grafik pada Gambar 8.

Tabel 1. Perbandingan Data Dengan Model VK Jenis Sepeda Motor (MC)

\begin{tabular}{crr}
\hline \multirow{2}{*}{ Tahun } & \multicolumn{2}{c}{ VK Jenis Sepeda Motor(MC) } \\
\cline { 2 - 3 } Rata-rata & \multicolumn{1}{c}{ Data } & \multicolumn{1}{c}{ Model } \\
\hline Standdev & $506,167.84$ & $627,620.68$ \\
\hline E1 & 0.013435372 & $516,160.15$ \\
\hline E2 & 0.019024702 & $1.34 \%$ \\
\hline
\end{tabular}

VK Jenis Sepeda Motor

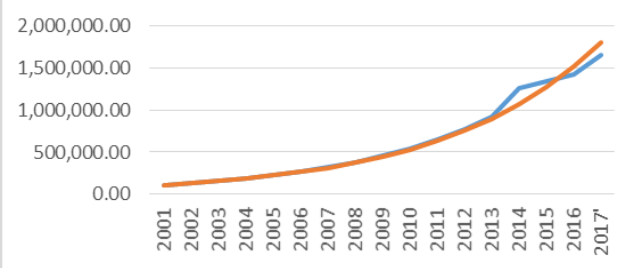

—VK Jenis (MC) Data $—$ VKJenis (MC) Model

Gambar 8. Grafik Perbandingan Sepeda Motor

\section{b. Validasi Sub Model Volume Kendaraan Ringan (LV) di Makassar}

Validasi sub model volume kendaraan ringan (LV) di Makassar, akan disajikan dalam Tabel 2 , Berdasarkan Tabel menunjukkan hasil validasi dengan nilai uji perbandingan rata-rata $4.78 \%$ dan uji 
ILKOM Jurnal Ilmiah Volume 11 Nomor 1 April 2019

Terakreditasi peringkat 3 SK. No. 28/E/KPT/2019

perbandingan variasi amplitude $17.50 \%$. Sesuai dengan standar nilai maksimum validasi data dimana $\mathrm{E} 1 \leq 5 \%$ dan $\mathrm{E} 2 \leq 30 \%$, maka hasil uji data volume kendaraan ringan dapat dinyatakan valid. Hasil pengujian volume kendaraan ringan (LV) di makassar disajikan dalam bentuk grafik pada Gambar 9.

Tabel 2. Perbandingan Data Dengan Model Volume Kendaraan Ringan (LV)

\begin{tabular}{crr}
\hline \multirow{2}{*}{ Tahun } & \multicolumn{2}{c}{$\begin{array}{c}\text { Volume Kendaraan Ringan } \\
\text { (LV) }\end{array}$} \\
\cline { 2 - 3 } & \multicolumn{1}{c}{ Data } & \multicolumn{1}{c}{ Model } \\
\hline Rata-rata & $92,264.50$ & $96,676.26$ \\
\hline Standdev & $75,974.47$ & $89,319.73$ \\
\hline E1 & 0.047816456 & $4.78 \%$ \\
\hline E2 & 0.175654539 & $17.50 \%$ \\
\hline
\end{tabular}

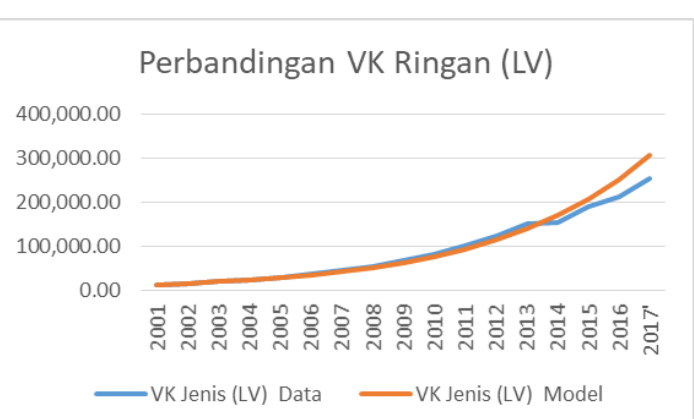

Gambar 9. Grafik Perbandingan Volume Kendaraan Ringan (LV)

\section{c. Validasi Sub Model Volume Kendaraan Berat (HV) di Makassar}

Validasi sub model volume kendaraan berat (HV) di Makassar, akan disajikan dalam tabel 3. Berdasarkan tabel tersebut, menunjukkan hasil validasi dengan nilai uji perbandingan rata-rata $0.76 \%$ dan uji perbandingan variasi amplitude $7.14 \%$. Sesuai dengan standar nilai maksimum validasi data dimana $\mathrm{E} 1 \leq 5 \%$ dan $\mathrm{E} 2 \leq 30 \%$, maka hasil uji data volume kendaraan berat dapat dinyatakan valid. Hasil pengujian volume kendaraan berat (HV) di makassar disajikan dalam bentuk grafik pada Gambar.10.

Tabel 3. Perbandingan Data Dengan Model Volume Kendaraan Berat (HV)

\begin{tabular}{crr}
\hline \multirow{2}{*}{ Tahun } & \multicolumn{2}{c}{ Volume Kendaraan } \\
\cline { 2 - 3 } & \multicolumn{1}{c}{ Data } & \multicolumn{1}{c}{ Model } \\
\hline Rata-rata & $37,368.91$ & $37,085.44$ \\
\hline Standdev & $24,689.75$ & $26,453.33$ \\
\hline E1 & 0.007585663 & $0.76 \%$ \\
\hline E2 & 0.071429767 & $7.14 \%$ \\
\hline
\end{tabular}

\subsection{Scenario Development}

\section{a. Skenario Penurunan Volume Kendaraan LV Melalui Program Rekonfigurasi Jaringan Rute terhadap Efisiensi Waktu Tempuh}

Skenario Rekonfigurasi Jaringan Rute pada Beberapa Jalan dilakukan dengan menggunakan aplikasi (petunjuk arah). Skenario ini bertujuan untuk mengurangi volume lalu lintas di jalan Urip Sumoharjo. Berdasarkan data yang tercatat, terdapat sejumlah kendaraan yang melintasi jalan Urip Sumoharjo kearah jala perintis kemerdekaan. Rute untuk mengarah ke perintis kemerdekaan ada dua yaitu rute yang melalui jalan Urip Sumoharjo dan rute yang melewati jalan tol, Jika sejumlah kendaraan tersebut dapat melewati rute lain atau rute alternative seperti jalan tol bagi pengguna kendaraan ringan pribadi (LV) maka volume lalu lintas di jalan Urip Sumoharjo akan menurun.

Dari data yang tercatat oleh Dinas Perhubungan Jumlah Kendaraan yang Melintasi jalan Urip Sumoharjo menuju ke jalan perintis kemerdekaan jenis kendaraan ringan sebanyak $50 \%$ dari total keseluruhan kendaraan ringan, sedangkan dari arah perintis menuju ke pettarani sebanyak $40 \%$ dari total keseluruhan kendaraan ringan. Jika pengendara tersebut diarahkan menggunakan jalan alternative maka volume lalu lintas dijalan Urip Sumoharjo akan menurun.

Adapun persamaan untuk skenario penurunan volume kendaraan LV melalui program Rekonfigurasi Jaringan Rute dapat diuraikan berikut ini :

- "Persentase kendaraan dialihkan dari arah pettarani menuju perintis $\langle\mathrm{SCN}\rangle "=(40 / 100) \ldots .(17)$

- "Persentase kendaraan dialihkan dari arah perintis menuju pettarani $\langle\mathrm{SCN}\rangle "=(20 / 100) \ldots .(18)$ 
ILKOM Jurnal Ilmiah Volume 11 Nomor 1 April 2019

Terakreditasi peringkat 3 SK. No. 28/E/KPT/2019

- "Jumlah kendaraan ringan (LV) yang dialihkan ke Rute Tol <SCN>" = IF THEN ELSE(Time>2017, "Average jumlah Kendaraan ringan (LV) di jalan Urip Sumohardjo"*("Persentase kendaraan dialihkan dari arah perintis menuju pettarani $<\mathrm{SCN}>$ "+"Persentase kendaraan dialihkan dari arah pettarani menuju perintis $\langle\mathrm{SCN}>"), 0$ )

- "jumlah volume LV (smp) di jalan urip sumoharjo" = "aturan besaran LV (smp)"*("Average jumlah Kendaraan ringan (LV) di jalan Urip Sumohardjo"-"Jumlah kendaraan ringan (LV) yang dialihkan ke Rute Tol $<\mathrm{SCN}>$ ").

Adapun nilai parameter skenario penurunan volume kendaraan LV melalui program Rekonfigurasi Jaringan Rute didapatkan dari hasil dari jumlah kendaraan dialihkan, berikut ini daftar nilai parameter dan penentuan nilai parameternya yang akan disajikan dalam Tabel 4.

Gambar 11 menunjukan angka volume kendaraan sebelum dan setelah dilakukan skenario menunjukan adanya perbedaan besar, ini dikarenakan program Rekonfigurasi Jaringan Rute dapat mengurangi volume lalu lintas. Gambar 12 menunjukan nilai kecepatan rata-rata sebelum dan setelah dilakukan skenario menunjukan adanya peningkatan. Skenario Penurunan Volume Kendaraan LV Melalui Program Rekonfigurasi Jaringan Rute Terhadap Waktu Tempuh (Travel Time). Gambar 13 menunjukan nilai waktu tempuh (travel time) sebelum dan setelah dilakukan skenario menunjukan adanya penurunan waktu tempuh secara signifikan.

Tabel.4. Nilai Parameter skenario penurunan volume LV melalui program Rekonfigurasi Jaringan Rute

\begin{tabular}{|c|c|c|c|}
\hline No & Nama Variabel & Nilai Parameter & $\begin{array}{c}\text { Sumber/ Dasar } \\
\text { Penelitian/ } \\
\text { Observasi }\end{array}$ \\
\hline 1 & $\begin{array}{l}\text { "Persentase kendaraan } \\
\text { dialihkan dari arah } \\
\text { pettarani menuju perintis } \\
<S C N>\text { " }\end{array}$ & $(40 / 100)$ & $\begin{array}{l}\text { Sumber } \\
\text { Informasi } \\
\text { DISHUB yang } \\
\text { di Asumsikan }\end{array}$ \\
\hline 2 & $\begin{array}{l}\text { "Persentase kendaraan } \\
\text { dialihkan dari arah } \\
\text { perintis menuju pettarani } \\
<\mathrm{SCN}>\text { " }\end{array}$ & $(20 / 100)$ & $\begin{array}{l}\text { Sumber } \\
\text { Informasi } \\
\text { DISHUB yang } \\
\text { di Asumsikan }\end{array}$ \\
\hline 3 & $\begin{array}{l}\text { "Jumlah kendaraan } \\
\text { ringan (LV) yang } \\
\text { dialihkan ke Rute Tol } \\
<S C N>\text { " }\end{array}$ & $\begin{array}{l}\text { IF THEN ELSE(Time>2017, "Average } \\
\text { jumlah Kendaraan ringan (LV) di jalan } \\
\text { Urip Sumohardjo"*("Persentase } \\
\text { kendaraan dialihkan dari arah perintis } \\
\text { menuju pettarani <SCN>" } \\
+ \text { "Persentase kendaraan dialihkan dari } \\
\text { arah pettarani menuju perintis } \\
<S C N>"), 0 \text { ) }\end{array}$ & $\begin{array}{l}\text { Observasi } \\
\text { langsung }\end{array}$ \\
\hline
\end{tabular}

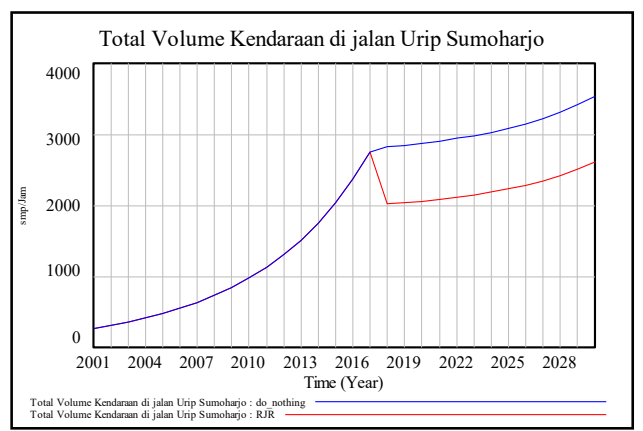

Gambar 11. Grafik Skenario Penurunan Volume Kendaraan Melalui program RJR

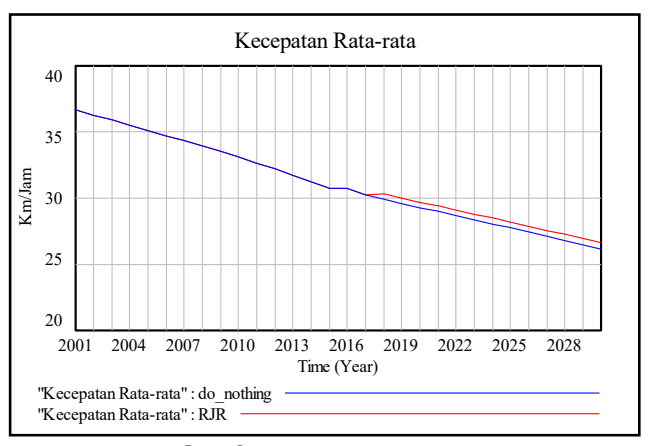

Gambar 12. Grafik Perbandingan Kecepatan Rata-rata 
ILKOM Jurnal Ilmiah Volume 11 Nomor 1 April 2019

Terakreditasi peringkat 3 SK. No. 28/E/KPT/2019

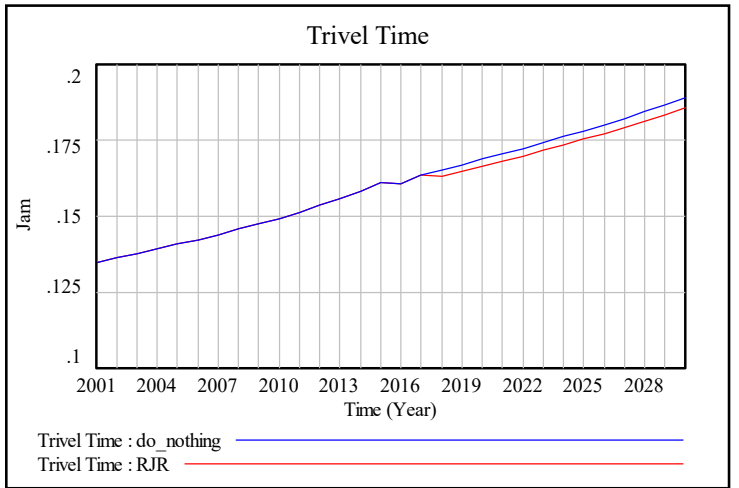

Gambar 13. Grafik Perbandingan Waktu Tempuh (Travel Time)

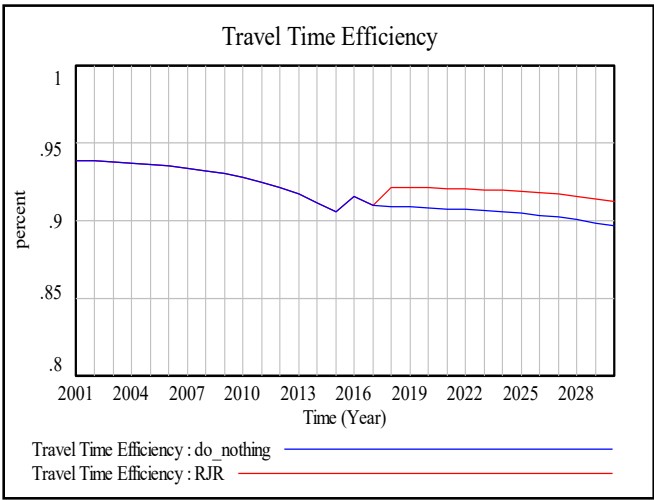

Gambar 14. Grafik Perbandingan Efisiensi Waktu Tempuh

\section{b. Skenario Terhadap Efisiensi Waktu Tempuh (Travel Time)}

Skenario penurunan volume kendaraan ringan (LV) melalui program rekonfigurasi jaringan rute yang diimplementasikan terhadap kondisi eksisting bertujuan untuk meningkatkan efisiensi dari sistem transportasi. Efisiensi waktu tempuh didapat dari waktu tempuh dibagi dengan waktu tempuh standard. Gambar 14 menunjukan nilai efisiensi waktu tempuh (travel time) sebelum dan setelah dilakukan skenario menunjukan adanya penurunan persentase yang menandakan lebih efisien dari sebelumnya.

\section{Kesimpulan}

Penelitian ini merepresentasikan kondisi yang terjadi saat ini, karena itu penelitian mensyaratkan untuk memahami sistem yang akan dibuat. Variabel atau parameter yang berpengaruh didapatkan dari beberapa penelitian yang menyebutkan baik secara tersirat maupun secara tertulis dalam jurnalnya. Model ini disusun mencakup setiap variabel yang terkait dalam meningkatkan Efisiensi terhadap waktu tempuh, biaya bbm dan jumlah emisi gas buang. Skenario yang diusulkan untuk meningkatkan efisiensi terdiri dari skenario rekonfigurasi jaringan rute pada beberapa jalan. Hasil simulasi trevel time dengan hambatan pada tahun 2018 sebesar 0.165 jam sedangkan pada tahun 2030 sebesar 0.189 jam, Waktu Tempuh (Travel Time) dengan Skenario Penurunan Volume Kendaraan LV Melalui Program Rekonfigurasi Jaringan Rute didapatkan trevel time pada tahun 2018 sebesar 0.163 jam, sedangkan pada tahun 2030 sebesar 0.185 jam.

\section{Daftar Pustaka}

[1] Pamudi and E. Suryani, "Penerapan Sistem Dinamik Dalam Sistem Transportasi Cerdas Untuk Mengurangi Kemacetan, Polusi Dan Meningkatkan Keselamatan Berlalu Lintas (Study Kasus Dinas Perhubungan Kota Surabaya)," 2018.

[2] M. M. S. M. a. M. W. Aslani, "Adaptive Traffic Signal Control with Actor-Critic Methods in a RealWorld Traffic Network with Different Traffic Disruption Events," Transportation Research Part C: Emerging Technology, 2017.

[3] W. Suwardjoko P, "Pengelolaan Lalu Lintas dan Angkutan Jalan," no. Penerbit ITB, 2002.

[4] D. Sagitariansyah, "Tinjauan Atas Analisis Efisiensi Penggunaan Modal Kerja Pada Perum Pegadaian Kantor Cabang Kiaracondong Bandung," no. Universitas Widyatama, 2011.

[5] S. E. Anto Aan, "Pendekatan Sistem Dinamik untuk Analisa Peningkatan Kepuasan Pelanggan Melalui Penyelarasan Tujuan Ti Dan Tujuan Bisnis," no. Institut Sepuluh Nopember, 2010.

[6] E. S. Y. C. R. H. a. C. H. C. Suryani, "Demand Scenario Analysis and Planned Capacity Expansion: A System Dynamics Framework," vol. Simulation Modelling Practice and Theory 18(6):732-51.

[7] A. S. A. Adhisasmita Rahardjo, "Manajeman Transportasi Darat. Mengatasi Kemacetan Lalu lintas di Kota Besar (Jakarta)," no. Graha IImu, 2011. 